\title{
The Greek public debt problem
}

O problema da dívida pública grega

\begin{abstract}
The present paper examines the issue of the Greek public debt. After providing a historical discussion, we show that the austerity of the last six years has been unsuccessful in stabilizing the debt while, at the same time, it has taken a heavy toll on the economy and society. The recent experience shows that the public debt is unsustainable and therefore a restructuring is needed. An insistence on the current policies is not justifiable either on pragmatic or on moral or any other grounds. The experience of Germany in the early post-WWII period provides some useful hints for the way forward. A solution to the public debt problem is a necessary but not sufficient condition for the solution of the Greek and European crisis. A wider agenda that deals with the malaises of the Greek economy and the structural imbalances of the Eurozone is of vital importance.
\end{abstract}

\section{Keywords}

Greece; public debt; austerity; Eurozone; crisis.

JEL Codes E62; F34; F41; N10; N94.
Michalis Nikiforos

Levy Economics Institute of Bard College

Dimitri B. Papadimitriou

Levy Economics Institute of Bard College

Gennaro Zezza

Università degli Studi di Cassino e del Lazio Meridionale

\section{Resumo}

O presente artigo examina a questão da dívida pública grega. Após oferecer um panorama histórico, mostramos que a austeridade dos últimos seis anos fracassou em sua tentativa de estabilizar a divida, ao mesmo tempo em que produziu intensos efeitos negativos sobre a economia e a sociedade. A experiência recente mostra que a divida pública é insustentável, e que uma reestruturação é necessária. Uma insistência nas políticas correntes não se justifica seja em termos pragmáticos, morais, ou de qualquer outra natureza. A experiência da Alemanha no imediato pós-Segunda Guerra Mundial oferece indicações valiosas acerca do caminho a ser seguido. Encontrar uma solução para o problema da dívida pública é uma condição necessária, porém não suficiente para equacionar as crises grega e europeia. Uma agenda mais ampla, direcionada para as deficiências da economia grega e para os desequilíbrios estruturais da Zona do Euro, será de importância vital.

\section{Palavras-chave}

Grécia; divida pública; austeridade; Zona do Euro; crise.

Códigos JEL E62; F34; F41; N10; N94. 


\section{Introduction}

The Greek economic crisis of the last seven years has been the most severe crisis that a developed economy has experienced in modern history, both in terms of output and employment loss as well as duration. In 2016, the real GDP of the Greek economy was 30\% below its 2008 level. Over the same period, more than one million people (in a labor force of 4.8 million in 2008) have lost their jobs. The situation in Greece is a testament to the catastrophic effect that austerity can exert on an economy and the disastrous consequences it can have for the social fabric.

One of the core issues in this contemporary Greek tragedy has been public debt. When the crisis started in 2009 with a debt-to-GDP ratio around $120 \%$, it was interpreted by most economists and policymakers as a public debt crisis. As a result, the austerity measures of the last six years have been imposed in order to address this problem. Fiscal consolidation, together with structural reforms, is supposed to generate large fiscal surpluses, reinvigorate investment, and enhance the competitiveness of the economy and thus net exports. The result of these efforts will be a slowdown of the increase in debt and a boost to growth and therefore a decrease in the debt-to-GDP ratio. Austerity and structural reforms are thus imposed to a large extent in the name of the sustainability of debt.

The reality of the Greek economy has disproved - quarter after quarter and year after year - this kind of projection. Instead of the promised expansion, the austerity has led to the aforementioned colossal loss of output and employment. Moreover, despite a haircut of the debt in 2012, public debt is now around 195\% of the Greek GDP (a ratio is very hard to decrease when the denominator falls by $30 \%$ ).

The goal of the present paper is to provide a comprehensive and wellrounded examination of the issue of the Greek public debt and its role in the crisis. We start with a historical discussion of the accumulation of the Greek public debt before 2009 and the reasons that led to the increase in the debt-to-GDP ratio over time. This discussion is necessary in order to understand the crisis and the future challenges facing the Greek economy, because the roots of the current crisis in Greece and the Eurozone need to be traced back to the Maastricht Treaty and the flaws in the design of the common currency area. From that point of view, the fiscal deficits and the accumulation of the public debt are the 
symptoms rather than causes of the Greek problem and therefore the prevalent diagnosis is wrong.

A historical account of the Greek public debt serves as a basis for the discussion of the role of the debt during the crisis. We make three main points. First, the imposition of austerity and "structural reforms" in the name of debt sustainability has pushed the economy into a debt-deflation trap: austerity leads to a fall in the GDP and thus an increase - ceteris paribus - of the fiscal deficit. These two effects lead to an increase in the debt-to-GDP ratio and make more austerity and more "structural reforms" necessary. The swirling of the Greek economy in this vicious cycle has grave social and political consequences.

Second, an examination of the uses of the bailout funds so far reveals who are the ultimate beneficiaries of the austerity. Recent estimates show that more than $95 \%$ of these funds have been used to (re)pay the country's foreign creditors or for the recapitalization of the domestic banking sector. Finally, we discuss some other functions of the public debt. Besides its reduction as the eventual goal of austerity, public debt has also acted as the "stick" and "carrot" for its imposition. The provision (or the lack thereof) of liquidity from the European Central Bank (ECB) to the Greek banks using public debt securities as collateral has been repeatedly used by the ECB as a discipline mechanism against deviations from the austerity path. At various stages in the endless negotiations, the promise of a debt restructuring has acted as the eventual reward for imposing yet another "difficult but necessary" austerity package (as was the situation in early May 2016, when this text was being written).

This discussion of the experience of the last six years shows that Greece's public debt is clearly unsustainable; therefore, we argue that a bold restructuring of the debt is needed for the Greek economy to reignite its engine of growth. An insistence on the current policies is not justifiable on pragmatic, moral, or any other grounds.

The experience of Germany in the early post-WWII period provides a useful lesson for the way forward. As it is explained in more detail below, in the aftermath of WWII there was a sweeping cancellation of the German public and foreign debt, which was part of a wider plan for the economic and political reconstruction of Germany and Europe.

Seven decades later, a solution to the unsustainability of Greece's public debt - through debt restructuring and a relaxation of austerity policies - is 
a necessary condition for a lasting solution to the Greek and European crisis. However, our discussion of the roots of the crisis and also the postWWII experience show that this is not sufficient. A sustainable solution requires a wider agenda that deals with the domestic malfunctions of the Greek economy and, most importantly, the structural imbalances of the Eurozone. In fact, the solution to these problems looks much more difficult compared to that of the debt.

The paper proceeds as follows. In the next section, we provide a historical account of the Greek public debt. Sections 3 to 5 discuss the crisis and the role of debt during the crisis. Section 6 calls for a restructuring of Greece's public debt and section 7 explains why this is justified on pragmatic and moral grounds. Section 8 summarizes the restructuring of the German debt in the early postwar period and the plans for the reconstruction of Europe at the time. Section 9 concludes.

\section{A brief historical perspective}

Before discussing the role of Greek sovereign debt during the current crisis, it is worth making a short historical discussion of its path over the last half century. Besides its historical interest, this discussion is necessary in order to understand the crisis and the future challenges of the Greek economy. A more detailed exposition is provided in Nikiforos et al. (2015).

\section{Figure 1 Sovereign debt-GDP ratio, 1960-2015}

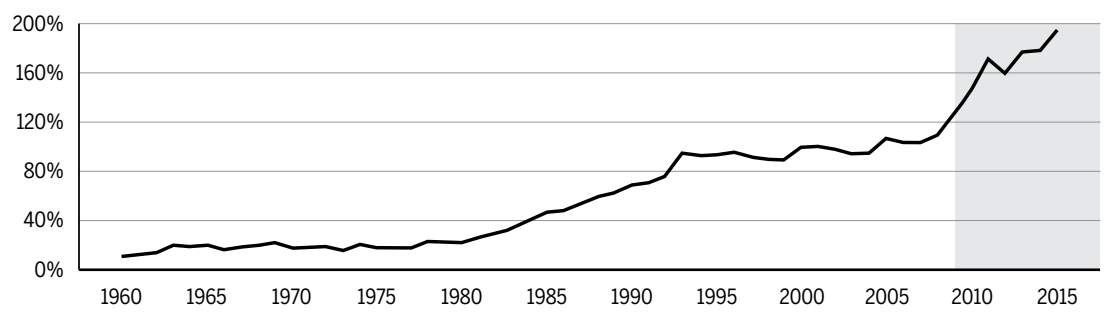

Source: World Development Indicators, AMECO.

In figure 1 , we present the ratio of public-debt-to-GDP for the period 1960-2015. The trajectory of the ratio can be divided broadly into four periods. The first extends between the beginning of our sample and the late 
1970s, while the second covers the years 1981-93. The third focuses on the period between 1993 and 2009. Finally, the fourth is the crisis period, extending from 2009 to the present, represented as the shaded period in figure 1 and subsequent figures.

During the first period until the late 1970s, the debt-to-GDP ratio remains stable at low levels, around $20 \%$. In conjunction with figures 2 and 3 , it is not hard to conclude that this stability is the result of relatively low fiscal deficits together with high growth rates.

The second period is the years between 1981 and 1993. In 1981, the overall government deficit increases by five percentage points to $78 \%$ and leads to a sharp increase in the debt-to-GDP ratio. This increase continues until 1993 when the ratio is $95 \%$. There are four main reasons behind this increase. The first is the increase in government expenditure for welfare, especially in the first part of the 1980s. Second is the low growth rate of the period, associated with the global economy slowdown, as well as idiosyncratic factors of the Greek economy. Third is increases in government spending related to the political cycle, as all the years that public deficit spikes during this period (1981, 1985, 1989, 1990, and 1993) are election years. Fourth relates to the high interest rates of that period due to the interest rate policy of the Federal Reserve. We see that the interest payments became an ever-increasing part of the government budget. This increase is obviously related to the increasing stock of debt and the increase in the yield due to the increase in the stock of debt, but also the increase in the interest rates of the US Federal Reserve during that period seemed to have played a role. For example, the increase in interest payments in the early 1980s cannot be justified by the debt level, which was still very low.

On February 7, 1992, Greece and eleven other European countries signed the Maastricht Treaty, which, among other things, defined the roadmap for the adoption of the common currency, the Euro, at the end of the decade. The Maastricht Treaty defined the so-called convergence criteria that a country had to fulfill in order to become a member of the Eurozone. The two most important of these criteria were the achievement of price stability and a low government deficit, not higher than $3 \%$ of GDP. As part of the unification process, the participating economies had to liberalize their capital markets and remove any controls in the flows of capital. The Maastricht Treaty came into force on November 1, 1993. 
Figure 2 Decomposition of government deficit (1970-2015)

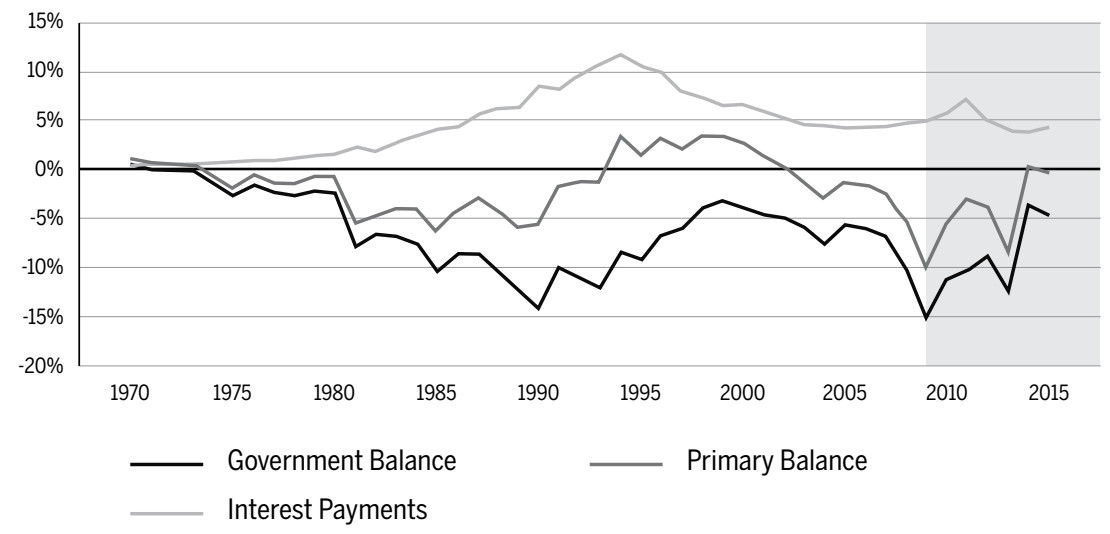

Source: World Development Indicators, AMECO.

As we can see in figure 1, this occurs - not coincidentally - with the beginning of the third period of the trajectory of debt-to-GDP ratio. Figure 2 shows that 1994 is the first year of a primary fiscal surplus. Positive primary results extend into the early 2000s. Fiscal consolidation, together with robust growth rates and a lower interest burden, led to stabilization of the debt-toGDP ratio. The ratio was 95\% in 2004 - exactly the same level as in1993.

Figure 3 Real GDP growth rate, 1961-2015

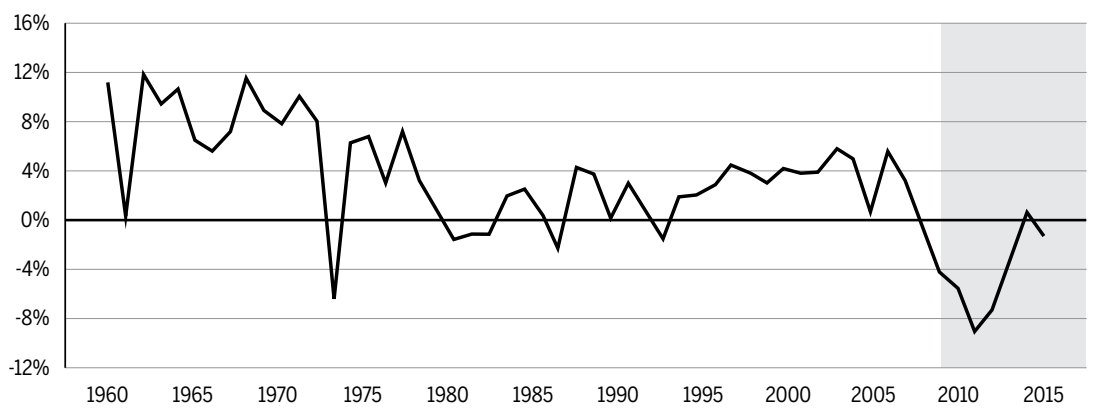

Source: World Development Indicators, AMECO.

However, it is in this period that we need to look for the roots of the Greek crisis. As part of the effort to lower the inflation rate and achieve price stability, in 1995 the Bank of Greece introduced the so-called hard-drachma 
policy, which set as an intermediate target to limit the year-over-year depreciation of the drachma against the European Currency Unit (ECU) to $3 \%$. The hard-drachma policy and the adoption of the common currency in 2001 led to an appreciation of the real exchange rate by almost $40 \%$ between 1995 and the beginning of the crisis in 2009.

Given the stability of the nominal exchange rate vis-à-vis the rest of the Eurozone countries, the real appreciation was the result of two main factors: the wage and price inflation differential with the Eurozone core economies and the nominal appreciation of the Euro in the period after 2001.Greece was successful in implementing price stability: The inflation rate decreased from above $20 \%$ in the beginning of the 1990s to around $3 \%$ by the end of the decade, where it remained until 2010. However, even this $3 \%$ was high compared to the core European countries. In Germany, the inflation rate in the period 1998-2007 never exceeded $2 \%$, and in most years was below $1 \%$. The convergence period was also crucial. In 1995, when the hard-drachma policy was announced, the inflation rate was still at double-digit levels. Finally, the nominal appreciation of the Euro can be understood with reference to the exchange rate with the US dollar, which increased by 85\% between January 2002 and March 2008 (from 0.86 to 1.6). More generally, the ECB index of the nominal exchange rate of the "euro area changing composition vis-a-vis the EER-12 group of trading partners" shows a nominal appreciation of around $50 \%$ between 2001 and 2009. ${ }^{1}$

The appreciation of the real exchange rate put an enormous amount of pressure on the Greek economy. As is shown in figure 4, it led to a shift from a balanced current account in 1995 to a deficit of more than $15 \%$ in 2008. This deficit could be financed for such a long period of time because it coincided with the euphoria that characterized the global financial markets during these years and the inflow of foreign capital that became possible after the capital markets liberalization that followed the Maastricht Treaty. Fifteen years of loss of competitiveness and increasing foreign deficits made these deficits structural.

In the face of increasing foreign deficits and fiscal consolidation, the robust growth rate of the period after 1993 became possible because of the increase in private-sector demand. The private sector in Greece was tradi1 The index can be found in the website of the Statistical Data Warehouse of the ECB at https://sdw.ecb.europa.eu/ 
tionally a net lender. Figure 4 shows that in 1993 the difference between private savings and investment stood at $10 \%$ of GDP. By 2002, this balance stood at $6.9 \%$ and in 2007 at $-8 \%$. As we mentioned above, the private sector was able to run deficits for so long because of the euphoria of the global financial markets and the capital inflows to the Greek economy; the stock market and real estate price inflation of the same period also helped.

Figure 4 Sectoral Balances, 1970-2015

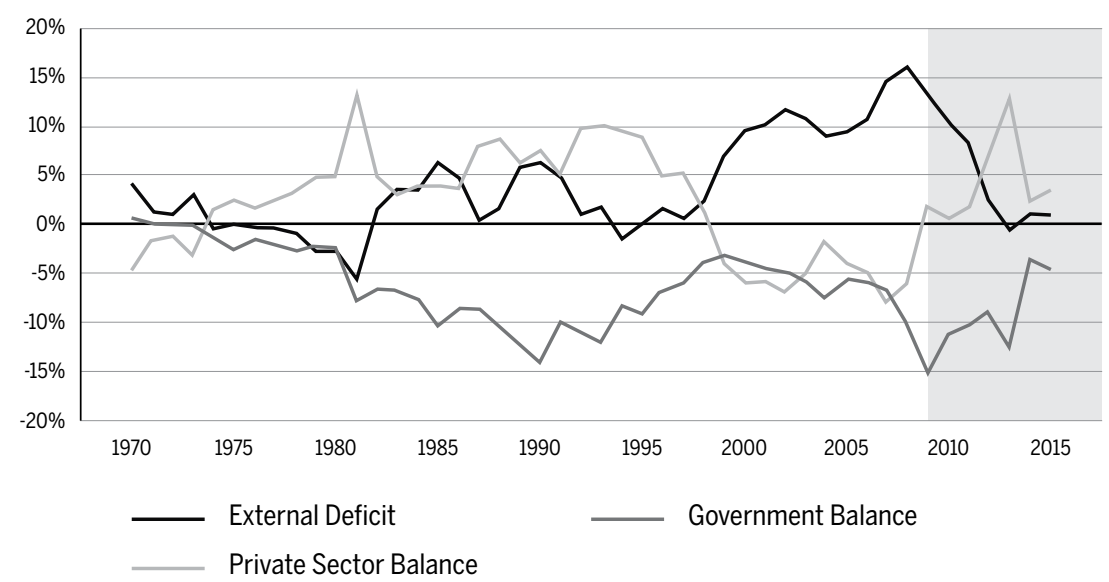

Source: World Development Indicators, AMECO.

Figure 4 also shows that in the face of increasing current account deficits, the government was able to consolidate its budget as long as the privatesector balance was decreasing. When the latter stabilized in the early 2000s, the pressure of the adjustment fell on the government, which was no longer able to maintain fiscal surpluses (figure 2). The fiscal pressures can also be seen in the debt-to-income ratio, which after eleven years of stability increases from $95 \%$ in 2004 to $109 \%$ in 2008 (figure 1).

In 2008, and especially in 2009 - under the burden of the global financial crisis and the rising private debt - when the private sector retrenched and switched from being a net-borrower to being a net-lender, structural foreign deficits were naturally reflected in the government balance. The 15\% of government deficit in 2009 was the mirror image of the current account deficit a year earlier. From this point of view, the crisis in Greece, which was initiated by this increase in the fiscal deficit - and more generally the 
crisis in the southern Eurozone periphery - is a current account crisis. The fiscal problems are merely a reflection of the root cause. This is important looking into the experience of the crisis and the future challenges of Greece and the Eurozone.

\section{The crisis}

If someone wants to define a date for the beginning of the Greek crisis it would be October 4,2009, the day of that year's parliamentary elections. A few days later the newly elected government announced that the fiscal deficit for 2009 would exceed $12 \%$ - double the $6 \%$ that the previous government was projecting before the elections. Eventually, the deficit ended up at $15.6 \%$. As we see in figure 1 , the debt-to-GDP ratio jumps by almost 20 percentage points that year to $127 \%$, the combined result of the deficit and the negative growth rate $(-4.3 \%$ in 2009$)$.

The announcement was followed by a series of rating downgrades of Greek treasury bonds and a steep increase in their yields by almost 600 basis points by the end of April 2010, effectively excluding Greece from access to the financial markets. In the face of a rollover of a significant part of the debt in May of 2010, a three-year rescue package was agreed to on May 2, 2010 between the Greek government and the "troika," the tripartite body of international lenders consisting of the European Commission, the ECB, and the International Monetary Fund (IMF).

The assistance was conditional on strict fiscal adjustment. According to the official IMF Staff Report on Request for Stand-By Arrangement (SBA), the primary fiscal balance was projected to increase from-8.6\% in 2009 to $3.1 \%$ in 2013 for an almost $12 \%$ fiscal consolidation. ${ }^{2}$ At the same time, Greece would have to implement a series of "structural reforms." As a result, the troika projected a shallow recession and a return to positive growth rates in 2012 driven by investment and net exports. Fiscal consolidation, together with return to growth, would stabilize and eventually decrease the debt-to-GDP ratio. These projections were in line with the theory of expansionary austerity. ${ }^{3}$

2 For the projections of the first Stand-By Agreement see IMF (2010).

3 The proponents of expansionary austerity are Alesina and Ardagna (1998); Alesina et al. (2012); Ardagna (2004); and Giavazzi and Pagano (1990). 
For better or worse, the predictions of the troika and the proponents of expansionary austerity were not fulfilled. The first phase of the program saw a significant decrease in the deficit; however, the fiscal consolidation and the "structural reforms" did not manage to boost investment or net exports and output collapsed. The collapse in output created further financing needs for the government and implementation of further measures of austerity that led, in their turn, to a deeper recession. The result, as figure 1 shows, was a rapid increase in the debt-to-GDP ratio from $127 \%$ in 2009 to $172 \%$ in 2011 . The economy spiraled downward in a modern debtdeflation trap à la Greca.

The increase in the debt-to-GDP ratio led to the realization that the Greek debt is not sustainable. The negotiations that started in the summer of 2011 led to a restructuring of the debt in 2012, hence the temporary decrease shown in figure 1 . However, it was "too little, too late." The cautious restructuring and the insistence on the same austerity policies led - not surprisingly - to the same results: deeper recession, the need for more fiscal austerity, and eventually, the increase in the debt-to-GDP ratio, which, as figure 1 shows, reached 195\% in 2015 with a further upward trend. Financing this increasingly heavy debt burden required two additional memoranda, one signed in March 2012 and another one in August 2015.

A quick account of the crisis shows that between 2008 and 2016, the Greek economy lost $30 \%$ of its real output and around one million jobs (in a labor force of 4.8 million in 2008). At a political level there were four different governments and four general elections over a period of five years (the tenure of the government according to the constitution is four years), accompanied by the rise into prominence of a neo-Nazi party, whose electoral influence rose from $0.3 \%$ in 2007 to $7 \%$ in 2015 .

\section{The bailout funds}

As we mentioned above, the adoption of austerity in Greece was encapsulated in three agreements detailing adjustment programs, which were signed between the Greek government and its foreign creditors. These 4 For a discussion of the debt restructuring of 2012, see Zettelmeyer et al. (2013) and Xafa (2014). 
three programs provided bailout funds in exchange for draconian austerity and structural reforms.

The first adjustment program was signed in May 2010. It was designed to run until June 2013 and had a planned size of $€ 110 \mathrm{bn} .{ }^{5}$ Out of this amount, €80bn was provided in the form of bilateral loans from other Euro-area member states under the Greek Loan Facility. The remaining $€ 30 \mathrm{bn}$ was provided by the IMF under the Stand-by Arrangement. The first program ended prematurely in March 2012 and was replaced by a second program. Because of the premature end of the first program, only $€ 73 \mathrm{bn}$ - out of the planned $€ 110 \mathrm{bn}$ - were finally disbursed: $€ 52.9 \mathrm{bn}$ from the Euro-area countries and $€ 20.1 \mathrm{bn}$ from the IMF.

The second program was planned to run until December 2014, but was eventually extended to June 2015 . The planned size of the second program was $€ 172.6 \mathrm{bn}$ : the sum of $€ 34.3 \mathrm{bn}$ from the first program, $€ 130.1 \mathrm{bn}$ in new funds, and a separate $€ 8.2 \mathrm{bn}$ loan from the IMF scheduled to be disbursed after 2014. The Euro-area countries contributed $€ 120.3 \mathrm{bn}$ plus the $€ 24.4 \mathrm{bn}$ of the first program that had not been disbursed, a total of $€ 144.7 \mathrm{bn}$. The funds were provided in the form of loans from the European Financial Stability Facility (EFSF) that had been created in the meantime for that purpose. ${ }^{6}$ The IMF contributed a total of $€ 28 \mathrm{bn}$, comprised of $€ 9.9 \mathrm{bn}$ of undisbursed funds from the first program, an equal amount of new contributions, and $€ 8.2 \mathrm{bn}$ in an additional loan. These funds were distributed under the Extended Fund Facility (EFF) of the IMF.?

Eventually, €153.8bn was disbursed: €141.8 billion from the Euro-area countries and $€ 11.9$ billion from the IMF. In February 2015, the Hellenic Financial Stability Fund (HFSF) repaid €10.9bn to the EFSF, bringing the net disbursed funds of the second adjustment program to $€ 130.9 \mathrm{bn} .^{8}$

The third adjustment program was agreed to in August 2015 and is

5 The numbers of this section were estimated by Rocholl and Stahmer (2016).

6 The EFSF was created as a temporary crisis resolution mechanism by the Euro-area member states in June 2010. It provided financial assistance to Ireland, Portugal, and Greece. It was replaced by a permanent rescue mechanism, the European Stability Mechanism (ESM), which started its operations in October 2012.

7 The EFF, as opposed to the SBA, is a longer-term assistance mechanism of the IMF.

8 The HFSF is a private entity with the purpose of "contribut[ing] to the maintenance of the stability of the Greek banking system." It was created in July 2010 and started its operations in September 2010. It was endowed with $€ 50 \mathrm{bn}$ in order to recapitalize the Greek banks. Eventually, the bank recapitalization of the period 2012-14 required $€ 39.1 \mathrm{bn}$ and the remaining $€ 10.9 \mathrm{bn}$ was returned to the EFSF in February 2015. 
scheduled to run until August 2018. The size of the program was originally €86 billion, provided by the European Stability Mechanism (ESM), which replaced the EFSF. As of the beginning of May 2016, €21.4bn has been disbursed. The original amount of $€ 86 \mathrm{bn}$ included $€ 25 \mathrm{bn}$ to be used for the recapitalization of the banks. Eventually less than $€ 10 \mathrm{bn}$ was used towards that purpose.

\section{Public debt and the crisis}

It is beyond the scope of this paper to provide a detailed account of the crisis, but it is worth making some comments related to the political economy of public debt and its role during the crisis. First, the official justification for fiscal austerity is debt sustainability and the austerity policies are imposed in the name of debt sustainability. The economic rationale of all three adjustment programs is that - according to the theory of expansionary austerity - fiscal consolidation and structural reforms will lead to economic growth. These two factors combined will then stabilize and eventually decrease the debt-to-GDP ratio and make debt sustainable. Figures 1 and 3 show that this has not worked so far. The linkage between austerity and public debt means that they are two issues that should be treated simultaneously. Austerity cannot stop without a debt cancellation. ${ }^{9}$ We will discuss this in more detail in the following section.

Another interesting aspect of the Greek public debt during the crisis is the evolution of its form and its holders. According to the financial accounts of the Bank of Greece, before the crisis in the second quarter of 2009 , $80 \%$ of total financial liabilities were in the form of bonds (longterm debt securities); $73 \%$ of these bonds were held abroad, mainly from banks or other financial corporations. In the third quarter of 2015, bonds accounted for only $12 \%$ of the total financial liabilities of the government, with half of them held abroad. The vast majority of government liabilities are now in the form of long-term loans from the official sector abroad, which accounted for $75 \%$ of total liabilities in 2015 q3 3 . They were only $9 \%$ in $2009 q 2$ and most probably they were not originating from the official sector. This evolution can be understood with reference to the previ9 Austerity without debt cancellation could take place if the ECB committed to roll over the debt, but this does not seem plausible right now. 
ous section, where it was explained that the vast majority of the bailout funds to the Greek government were given in the form of loans - either bilateral loans on behalf of the European government or through the EFSF, the ESM, and the lending facilities of the IMF (the SBA and the EFF).

Moreover, the first fiscal adjustment program allowed financial corporations abroad to unload a significant part of the stock of Greek public debt they held at the beginning of the crisis. Around half of this debt was bought at the time by the Greek domestic sector, mostly banks. The effect of the subsequent 2012 debt restructuring on the balance sheets of Greek banks was higher than it would have otherwise been. In turn, that required more public borrowing for the bank recapitalization that took place in 2013 and contributed further to the increase in the public debt. In other words, to a certain extent the adjustment program of Greece bailed out the big financial institutions abroad - mainly in Europe - that held the lion's share of the debt at the beginning of the crisis. This dimension of the Greek bailout was confirmed in a recent evaluation of the Greek program by the IMF (2015). The IMF justifies its involvement in the Greek program without an upfront debt cancellation because of the "risks of systemic international spillovers" and "contagion" (p. 38). ${ }^{10}$

It is also important to note that the loans to the Greek government during the crisis period have almost in their entirety flowed back to the foreign creditors of the country and have been used for the recapitalization of the banks. In the previous section, we explained that the net total size of the loans to Greece from the two first adjustment programs was $€ 215.9 \mathrm{bn}$, with €183.9bn coming from European sources and the remaining €32bn from the IMF. A recent paper by Rocholl and Stahmer (2016) examines where these funds were directed. As we show in figure 5, they estimate that $€ 86.9 \mathrm{bn}$ (or $40.3 \%$ of the total loans) were used for repayment of the debt, $€ 52.3 b n$ (or $24.2 \%$ ) for interest payments, €37.3bn (or 17.3\%) for the recapitalization of the Greek banks, and $€ 29.7$ bn (or 13.8\%) for the Private Sector Involvement (PSI) sweetener when the debt was restructured in 2012. It follows that out of the total loans of $€ 215.9 \mathrm{bn}$, only $€ 9.7 \mathrm{bn}$, a mere $4.5 \%$, were used to cover actual primary deficits (other than those related to the recapitalization of the banks). These numbers, in conjunction with the discussion in the previous paragraph, testify that the Greek 10 A recent discussion of the involvement of the IMF in the first adjustment program is provided by Blustein (2015). 
adjustment programs have served as a - direct or indirect - bailout of the foreign creditors of the country (the private and the official sector) as well as the domestic banking sector.

\section{Figure 5 Where did the funds of the first two adjustment programs go?}

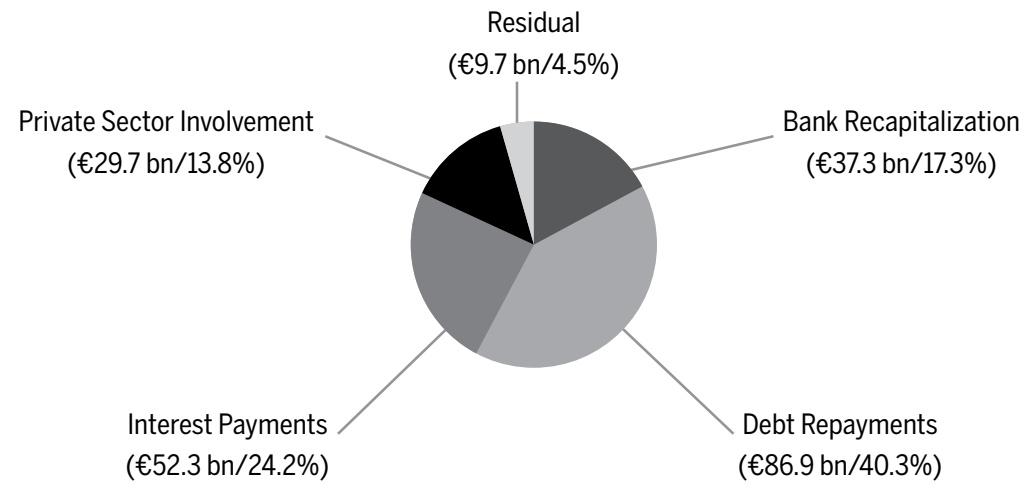

Source: Rocholl and Stahmer (2016).

Note: The net total size of the first two adjustment programs was $€ 215.9 \mathrm{bn}$.

Another interesting dimension of the public debt is its role as the "stick" for the imposition of austerity. A very fundamental characteristic of the Eurozone is that its central bank, the ECB, is supranational, so individual countries do not have control of the monetary authority. This kind of central bank independence is a very positive characteristic of the Eurozone according to the neoclassical theory and it was hardwired in its structure by the Maastricht Treaty. ${ }^{11}$ However, it creates various complications, two of which are relevant for our argument here. First, the ECB did not intervene in the markets to keep the bond yields under control when the crisis started; it took three years for the ECB chair to make his famous "whatever it takes" pledge in the summer of 2012. Had the ECB intervened in the bond markets since the very beginning, there would have been enough time to put together a plan that would solve the real structural issues of Greece and the Eurozone without falling into the debt-deflation trap of the last six

11 For the theoretical underpinning of the benefits of central bank independence, see Kydland and Prescott (1977) and Barro and Gordon (1983). The basic idea is that when the central bank is not independent it tends to create inflation without any benefits for employment, since unemployment is always at its natural rate. Therefore, the central banker has to be as independent and "conservative" as possible. 
years. More generally, the member states of the Eurozone find themselves at the discretion of a supranational institution, the ECB, over which they have very little control. The ECB then uses the public debt - or, more precisely, its power to intervene in the public debt markets - as the lever for the imposition of austerity and structural reforms. ${ }^{12}$

Related to that, the banking sector of Greece and the other Eurozone countries depend - especially during the crisis - on the liquidity provided by the ECB (in the same way that the banks in any country around the world depend on the liquidity of their central bank). Liquidity is provided with the use of government bonds as collateral. This is another serious policy constraint for Eurozone economies that is important in understanding the crisis. Any "unilateral action" on behalf of a Eurozone economy or failure to make its debt payments on time can lead to a stop to the liquidity provision and a collapse of the banking system. The experience of the Greek public sector in the first half of 2015 is telling in that respect.

Finally, during the Greek crisis of the last six years, public debt has also played the role of the "carrot." In various instances of the never-ending negotiations, there has been an implicit promise on behalf of the international lenders of the country that there will be a debt cancellation. For example, during the negotiations in the summer of 2015, the European authorities (unofficially) promised a reduction of the debt after an agreement was reached. Six months later this has not happened. The carrot is still hanging there.

\section{Why is a restructuring of Greek debt necessary?}

The above discussion makes clear that the reason for the need of a bold cancellation of the Greek debt is, first and foremost, the simple fact that it cannot be repaid under any plausible assumptions. As a result, the extension of the current policies that target high fiscal surpluses in the name

12 Famously, on August 5, 2011, the then-president of the ECB, Jean-Claude Trichet, sent a letter to Spanish Prime Minister José Luis Rodríguez Zapatero, in which he writes that the "ECB governing council discussed the situation of Spain's government bond markets" and sees "a need for further significant measures to improve the functioning of the labour markets." The connection of the structural reforms with the intervention of the ECB in the bond markets is very clear. 
of debt sustainability will lead to a deepening of the recession - or a prolonged period of stagnation - with all the consequences that the Greek economy and society has experienced all these years.

Moreover, because the unsustainability of the debt is obvious to everyone except for the official sector of the Eurozone, the debt overhang creates uncertainty that prohibits a recovery in investment activity on behalf of the private sector. Finally, precious resources that could be used to put an end to the depression of the last five years and lead to a recovery are sacrificed for the servicing of this clearly unsustainable stock of debt.

We saw that since the beginning of the crisis, Greece's international lenders argued that the public-debt-to-GDP ratio could be sustained through a combination of consecutive years of public surpluses together with a very strong positive reaction in the foreign sector and investment that would lead to a high growth rate. Despite reality having disproved this approach, its tenets survive to this day. For example, the latest review of the Greek program in the summer of 2014 - four years after the first adjustment program was agreed to - forecasted:

- A primary surplus of $3 \%$ of GDP in 2015 and then more than $4 \%$ between 2016 and 2022;

- A net export surplus of $2.1 \%$ of GDP in 2015 that will increase over time and converge to $4.1 \%$ of GDP by 2022 ;

- A strong rebound in investment - the forecast is a growth rate of real fixed capital formation of $9.7 \%$ in $2015,13.7 \%$ in $2016,11 \%$ in 2017 , and more than $7 \%$ in the following two years.

As a result of the last two, and despite the high fiscal surpluses, the economy was projected to achieve a very robust growth rate: $2.9 \%$ in 2015 , around $3.5 \%$ in the following four years, and would then converge to $2 \%$ by $2022 .^{13}$

The combined effect of these processes would be a decrease in the debt-to-GDP ratio of the Greek economy, since the numerator of this fraction will decrease and the denominator will increase rapidly. According to this projection, the ratio would have fallen below $120 \%$ by 2022 .

These numbers from the summer 2014, like those of May 2010, were 13 For the last review of the second adjustment program, see IMF (2014). Since the summer of 2014,no review of the Greek program has been made because of the failure to conclude a review in the fall of 2014, the elections of January 2015, the six months of negotiations, and eventually the agreement for a third program in August 2015. The first review of this third program started in January 2016 but, as of February, no one knows how long it will take. 
consistent from an accounting point of view. However, it was impossible that they would materialize and could be characterized - in the best case - as wishful thinking, as most of the forecasts of the troika have been thus far. There is no historical precedent of such a miraculous expansion of an economy in the face of public surpluses of more than $4 \%$ of GDP. Not surprisingly, the projections were once again falsified and this, as before, was attributed to the "weakening commitment to reforms" on behalf of the Greek government.

The third adjustment program, which was signed in the summer of 2015 , moves along the same lines. ${ }^{14}$ It projects - again - fiscal consolidation (a fiscal surplus target of $3.5 \%$ by 2018) combined with structural policies to "enhance competitiveness and growth." For the same reasons as in the recent past, these targets are unlikely to materialize. Given the recent performance of the Greek economy and the conditions of the European and global economy, it is also hard to see where the rebound in investment and net exports will come from. The continuation of the current policies with the sole goal of fiscal surpluses will lead - in the best-case scenario to a stagnation of the Greek economy, with high unemployment rates and further increases in the debt-to-GDP ratio. ${ }^{15}$

It is worth mentioning that the international lenders of the country are now more cautious regarding debt sustainability. The debt sustainability analysis of European institutions that accompanied the third memorandum shows that under no scenario will the debt-to-GDP ratio fall to the desired $120 \%$ by 2020 . However, there is no mention of debt cancellation. On the other hand, the IMF has been more vocal lately in its support for debt relief (which will accompany the structural reforms).

It is also important to note that although these facts have been swept under the carpet by the Eurozone officials (and until recently by the IMF), they are very well-known to the markets and the private sector in general. As a result, the debt overhang stands as a modern "Sword of Damocles" above the Greek economy that creates uncertainty and prevents any serious investment activity.

14 The various documents related to the third adjustment program can be found here: http:// ec.europa.eu/economy_finance/assistance_eu_ms/greek_loan_facility/index_en.htm.

15 Our recent projections for the Greek economy are summarized in our latest Strategic Anal$y$ sis (Papadimitriou et al. 2016). We have repeatedly stressed the implausibility of the troika's projections in various recent analyses of the Greek economy, e.g., Papadimitriou et al.(2013; 2014a,b,c; 2015). 
Finally, as we can see in figure 2, although the interest on the Greek debt has been significantly lowered in the recent period, the income payments of the Greek government to the holders of its debt absorb a significant amount of resources. We have demonstrated in several policy reports that these resources could have beneficial results if they were channeled towards public investment programs.

\section{Some other dimensions of the problem}

The need for the restructuring of Greek debt is usually opposed on moral(istic) grounds. The usual argument of the advocates of austerity goes as follows: The accumulated debt is part of past excesses of the Greek government and the Greek people, the corruption of the Greek political system, the dysfunctional public sector, and the high rate of tax evasion. Thus, the Greeks have to endure a prolonged period of austerity and pay for it.

This argument certainly has some merit. It is true that there is a corruption and tax evasion problem in Greece. It is also true that the public sector is dysfunctional and that Greek governments at certain points in the past have been imprudent and spent excessively.

However, the issue at hand is much more complicated than this. First, as we mentioned above, and the experience of the last six years has proven, the full repayment of the Greek debt is not pragmatic. The debt cannot be repaid under any plausible circumstances, and the longer we ignore this reality, the worse it will be for the Greek economy and for the European economy as a whole.

Second, as we explained in section 2, the Greek fiscal problem is, to a large extent, the result of the structural problems of the Eurozone. The policies that were put into place after the signing of the Maastricht Treaty in 1992 and the adoption of the Euro in 2001 exerted a large negative impact on the foreign sector of the Greek economy and led to a gradual increase in the current account deficit. The fiscal deficits of this period reflect the worsening of Greece's external position as the government attempted to stabilize the economy. In turn, these deficits could be ignored for such a long period of time - close to 15 years - only because of the euphoria in global financial markets during the same period. It is not coincidental that the debt crisis in Greece and throughout Europe erupted after the global financial crisis of 2008. 
Related to the structural deficiencies of the Eurozone, the Greek crisis has been exacerbated because the public debt is de facto denominated in a foreign currency - that is, as a member of the monetary union, Greece no longer has a central bank that can act as lender of last resort. If this were not the case, the country would not have found itself in such a diresituation. Even now, should the ECB guarantee the rollover of the existing debt, Greece would only have to worry about the sustainability of its current account.

Third, from a moral standpoint, the cost of default has to be shared between the creditor and the debtor. The existence of a positive real interest rate for borrowing - at least to a certain extent - is supposed to represent the existence of a risk of default. For that reason, because the risk of default differs among countries, the interest rate also varies. During the current crisis, in the case of Greece and elsewhere, creditors have been exempted from any responsibility for their lending behavior before the crisis began, and after which they were generously bailed out. Instead, the burden has fallen unilaterally on the shoulders of the debtors. This is clearly a biased interpretation of morality.

Fourth, even if Greece could repay its debt and there were no structural imbalances in the Eurozone, would the sacrifice be justified on purely moral grounds? The Greek economy has already experienced the largest peacetime decrease in GDP of any developed country in modern history. Is this sacrifice, and the further sacrifices that the adjustment programs require, morally justified?

John Maynard Keynes provides an interesting answer to this question in The Economic Consequences of the Peace. As is well known, in 1919 Keynes was a member of the British delegation at the Versailles conference, which produced the eponymous treaty that officially ended the war between the Allied powers and Germany and defined the reparations that Germany had to pay. ${ }^{16}$ Keynes attacked what he called the "Carthaginian peace" of the treaty. The main body of his argument is pragmatic in nature: he argued that the reparations numbers generally exceeded Germany's capacity to pay. As a result, and similar to the Greek situation today, the provisions of the treaty would not only lead to the destruction of the German economy, but they would also be in vain.

16 The exact schedule of the payments of the reparations was defined at a conference in London two years later. 
Keynes goes one step further and asks: even if Germany could pay the reparations, would the consequences of the peace be justifiable on moral grounds? His answer is a resounding no:

The policy of reducing Germany to servitude for a generation, of degrading the lives of millions of human beings, and of depriving a whole nation of happiness should be abhorrent and detestable, - abhorrent and detestable, even if it were possible, even if it enriched ourselves, even if it did not sow the decay of the whole civilized life of Europe. Some preach it in the name of Justice. In the great events of man's history, in the unwinding of the complex fates of nations Justice is not so simple. And if it were, nations are not authorized, by religion or by natural morals, to visit on the children of their enemies the misdoings of parents or of rulers. (Keynes 1919 [2014], p. 142; emphasis added).

Note how Keynes turns the whole morality (or justice) argument on its head. According to the winners of the war, it was just and moral that Germany should pay reparations. This is what the loser in a war was supposed to do. However, according to Keynes, "Justice is not so simple," and "degrading the lives of millions of human beings, and ... depriving a whole nation of happiness" is neither moral nor just. It is also significant that he put forward this argument shortly after the deadliest war in the history of his country.

Finally, in a similar vein, Keynes warns that the stubborn insistence on demanding reparations that could never be repaid would lead to a serious economic crisis that, in turn, could have serious political repercussions for Germany and the rest of Europe:

Men will not always die quietly. For starvation, which brings to some lethargy and a helpless despair, drives other temperaments to the nervous instability of hysteria and to a mad despair. And these in their distress may overturn the remnants of organization, and submerge civilization itself in their attempts to satisfy desperately the overwhelming needs of the individual. This is the danger against which all our resources and courage and idealism must now co-operate. (p. 144)

Unfortunately, history confirmed Keynes's predictions. The economic strain exerted by the reparations demands - and, more generally, the Allies' treatment of Germany immediately after the war and into the next decade - was one of the main factors in the Nazi party's rise to power in the late 1920s, setting the stage for World War II.

Keynes's arguments are of obvious relevance to the Greek problem today. The depth of the crisis that the Greek economy has been subjected to in the cause of debt repayment is not justifiable from a moral point of view, even if it could eventually lead to a lower debt-to-GDP ratio. Most importantly, the political repercussions of the crisis have already been se- 
vere for Greece, with the rise to prominence of a neo-Nazi party, the influence of which is bound to increase if the current situation continues.

From a historical perspective, it is both interesting and ironic that Germany today finds itself on the other end of the argument. Like England, France, and the United States in 1919, it is Germany that now stands as the modern guardian of "justice" and "morality."

\section{The restructuring of German public debt post-WWII}

Another irony of history is that Germany, which staunchly opposes any effort to restructure the Greek public debt, was the beneficiary of the largest debt restructuring deal in history in the aftermath of World War II. This debt cancellation was one of the main factors that ushered in the "German economic miracle" of the postwar period.

Germany came out of the war with a massive amount of debt, both external and domestic. The external debt can be decomposed into three main parts:

1) Prewar debt of around DM13.5bn that was related to reparations following World War I. This debt had not been serviced since 1933, and the figure does not include the interest foregone.

2) Post-World War II debt related to reconstruction loans received mainly through the Marshall Plan, amounting to DM16.2bn.

3) External debt accumulated during World War II, in the range of DM85bn to DM90bn (Ritschl 2012a).

These numbers do not include any reparations related to World War II, which were never calculated or paid.

To get an idea of the order of magnitude, German GDP in 1938 was around 100bn reichsmarks, while the GDP of West Germany in 1950 was at most DM100bn. ${ }^{17}$ Thus, the external debt amounted to roughly $120 \%$

17 The deutsche mark (DM) was introduced as part of a general currency reform in 1948, replacing the German reichsmark. Under the reform, all nominal assets were converted at a ratio of 10:1. For example, an asset with a nominal value of 10 reichsmarks was exchanged for a nominal asset worth one DM. Claims against the state, which were completely wiped out, were an important exception to this conversion. To avoid the collapse of the banking system, banks were given claims against the state that covered the discrepancy between the 
of German GDP.

The London Debt Agreement of 1953 restructured Germany's prewar and postwar debt - items (1) and (2) above. ${ }^{18}$ As a result,

a) The prewar and postwar debts of Germany were reduced to almost half, from DM29.7bn to DM14.3bn.

b) No interest was charged for the period after 1933 when the debt had not been serviced and the repayment interest rate for the debt of DM14.3bn that remained after the agreement was significantly reduced.

c) A five-year grace period (1953-58) was given to Germany during which only interest payments were due. During this period, Germany had to pay an annual interest of DM567mn. In the period after 1958, Germany had to make annual payments of DM765mn.

Finally, the external debt that was accumulated during the war - let alone any reparations - was never repaid.

Unlike what is widely supported in the public discourse, the above numbers show that the provisions of the London Agreement were only the tip of the iceberg in the cancellation of Germany's total external debt at that time.

These figures do not include the benefit from the interest foregone. At a rate of $3 \%$, around $\mathrm{DM} 3 \mathrm{bn}$ in annual income transfers to foreign countries was avoided. This is a very significant amount given that West German exports totaled no more than DM8bn in 1950. For Germany to find DM3bn without a contraction of its GDP and imports would have required a $40 \%$ increase in exports. ${ }^{19}$

Germany also had public debt, which amounted to roughly $379 \mathrm{bn}-$ reichsmarks in 1944. This amount includes the 8bnreichsmarks in external debt accumulated during World War II, included in (3) above. This public debt was restructured through a currency reform in 1948 that introduced the deutsche mark in the western occupation zones (see footnote 13). Germany's domestic public debt, which amounted to approximately $370 \mathrm{bn}$ reichsmarks in 1944 - total public debt of $379 \mathrm{bn}$ minus the $8 \mathrm{bn}$ included

assets and liabilities that resulted from the reform. Finally, recurring payments (wages, rents, pensions, etc.) were converted at a 1:1 rate. Details of the currency reform are provided in Deutsche Bundesbank (2002) and Lutz (1949).

18 For more details on the London Conference of 1953, see Guinnane (2004) and Kaiser (2003). 19 For more details on the London Conference of 1953, see Guinnane (2004) and Kaiser (2003). 
as part of the external debt - was reduced to only DM18bn as a result of the reform (Ritschl 2012b).

The sum total of the above is staggering. DM350bn in domestic debt (due to the currency reform of 1948), plus DM15bn in debt reduction after the London Agreement of 1953, plus DM90bn wartime debt that was never repaid amounts to DM455bn - more than four times German GDP in 1938 or West German GDP in 1950. ${ }^{20}$ Again, these figures do not include any kind of war reparations or interest foregone.

Most importantly, restructuring of the German debt took place as part of a wider economic plan for the reconstruction of Europe, which entailed the establishment of several institutions that promoted cooperation among European countries. The Organisation of European Economic Co-operation, or OEEC (precursor to the Organisation for Economic Cooperation and Development), is a significant example of this kind of institution. The OEEC was the venue for the European Payments Union, established in 1950, which allowed for the immediate rebooting of trade among the European economies without current account convertibility. ${ }^{21}$

Moreover, there was an implicit agreement that Germany would be allowed to repay its remaining debt through an expansion of its exports. It was understood that Germany could be the only economy in Europe that could be a major capital exporter to the rest of the continent. As a result, the German economy was reoriented toward export-led growth. ${ }^{22}$ In this sense, the postwar German economic miracle and the robust development of the rest of the European economies was not the result of abstract market forces. Instead, they were based on very specific and detailed planning.

\section{Conclusions: lessons for the present and the future}

Based on the previous discussion, we can make some brief points about the Greek public debt problem, as well as the Greek and the European crisis.

20 Obviously the GDP of both West and East Germany in 1950 was higher than that and most of the debt was incurred by the unified Germany of the prewar period and during the war.

21 For details on the European Payments Union, see Eichengreen and de Macedo (2001).

22 The plan was devised mainly by the United States; see Guinnane (2004) and Berger and Ritschl (1995). 
First, Greece needs a cancellation or significant write-down of its public debt. The insistence on full repayment of its debt is not justified on either pragmatic or moral grounds. Moreover, as the past has shown, these situations can have dangerous political repercussions.

Second, the cancellation of the German debt following World War II provides a template for such an arrangement. As explained above, this debt cancellation was farreaching.

Third, sovereign debt restructuring is a necessary but definitely not sufficient condition for the solution to the crisis in Greece and the rest of Europe. Another necessary condition is that the restructuring is accompanied by a relaxation of austerity.

Finally, and related to that, the post-World War II developments point to another necessary condition for the solution of the crisis in Greece and the rest of Europe. As happened in the early postwar period, the restructuring needs to be part of a wider plan to deal with the malaise of the Greek economy and, most importantly, with the structural problems of the Eurozone as a whole. Solving these problems seems to be much more challenging than dealing with the issue of Greece's sovereign debt.

\section{References}

ALESINA, A.; FAVERO, C.; GIAVAZZI, F. The output effect of fiscal consolidation. NBER Working Paper 18336. Washington, DC: National Bureau of Economic Research, 2012.

ALESINA, A.; ARDAGNA, S.Tales of fiscal adjustment. Economic Policy, v.13, n. 27, p. 487-545, 1998.

ARDAGNA, S. Fiscal stabilizations: When do they work and why. European Economic Review, v.48, n.5, p.1047-74, 2004.

BERGER, H.; RITSCHL, A. Germany and the Political Economy of the Marshall Plan, 194752: A re-revisionist view. In:EICHENGREEN, B. (Ed.). Europe's Post-War Recovery. Cambridge: Cambridge University Press, 1995, p.199-245, 1995.

DEUTSCHE BUNDESBANK. Circulation of the Deutsche Mark - from Currency Reform to European Monetary Union. Monthly Report, v.54, n.3, p.19-34, 2002.

BARRO, R. J.; GORDON, D. B. A positive theory of Monetary Policy in a Natural Rate Model. Journal of Political Economy, v.91, n.4, p.589-610, 1983.

BLUSTEIN, P. Laid Low: The IMF, the Euro Zone and the First Rescue of Greece. CIGI Papers No 61. Ontario: Centre for International Governance Innovation, 2015.

EICHENGREEN, B.; MACEDO, J. B. de. The European Payments Union: History and implications for the evolution of the International Financial Architecture. In:LAMFALUSSY, A.; 
SNOY, B.; WILSON, J. (Eds.) Fragility of the International Financial System: How can we prevent new crises in emerging markets. Brussels: Presses Interuniversitaires Europeennes. p. 25-42, 2001.

GIAVAZZI, F.; PAGANO, M. Can severe fiscal contractions be expansionary? Tales of two small European countries. NBER Working paper 3372. Washington, DC: National Bureau of Economic Research, 1990.

GUINNANE; T. W. Financial Vergangenheitsbewaeltigung: The 1953 London Debt Agreement. Yale University Economic Growth Center Discussion Paper No. 880. New Haven, CT: Yale University Economics Growth Center, 2004.

INTERNATIONAL MONETARY FUND (IMF). Greece: Staff Report on Request for Stand-By Arrangement. IMF Country Report 10/110. Washington, DC: International Monetary Fund, May 5, 2010.

INTERNATIONAL MONETARY FUND (IMF). Greece: Fifth review under the extended arrangement under the extended fund facility. Country Report No. 14/151. Washington, DC: International Monetary Fund, June 10, 2014.

INTERNATIONAL MONETARY FUND (IMF). Crisis Program Review. Washington, DC: International Monetary Fund, November 9, 2015.

KAISER, J. One made it out of the debt trap: Lessons from the London Debt Agreement of 1953 for current debt crises. International Policy Analysis. Bonn and Berlin: Friedrich-Ebert-Stiftung, 2003.

KEYNES, J. M. The economic consequences of the peace. In: The Collected writing of John Maynard Keynes, Volume II. Cambridge: Cambridge University Press, ([1919] 2014).

KYDLAND, F. E.; PRESCOTT, E. C. Rules rather than discretion: The inconsistency of Optimal Plans. Journal of Political Economy, v.85, n.3, p.473-92, 1977.

Lutz, F.A. The German Currency Reform and the revival of the German Economy. Economica, v.16, n.62, p.122-42, 1949.

NIKIFOROS, M.; CARVALHO, L.; SCRODER, C. Twin deficits in Greece: In search of causality. Journal of Post Keynesian Economics, v.38, n.2, p.302-30, 2015.

PAPADIMITRIOU, D. B.; NIKIFOROS, M.; ZEZZA, G. The Greek Economic Crisis and the experience of austerity. Strategic Analysis. Annandale-on-Hudson, NY: Levy Economics Institute of Bard College, 2013.

PAPADIMITRIOU, D. B.; NIKIFOROS, M.; ZEZZA, G. Prospects and Policies for the Greek Economy. Strategic Analysis. Annandale-on-Hudson, NY: Levy Economics Institute of Bard College, 2014a.

PAPADIMITRIOU, D. B.; NIKIFOROS, M.; ZEZZA, G. Will Tourism Save Greece? Strategic Analysis. Annandale-on-Hudson, NY: Levy Economics Institute of Bard College, $2014 \mathrm{~b}$.

PAPADIMITRIOU, D. B.; NIKIFOROS, M.; ZEZZA, G. Is Greece Heading for a Recovery? Strategic Analysis. Annandale-on-Hudson, NY: Levy Economics Institute of Bard College, 2014c.

PAPADIMITRIOU, D. B.; NIKIFOROS, M.; ZEZZA, G. Greece: Conditions and Strategies for Economic Recovery. Strategic Analysis. Annandale-on-Hudson, NY: Levy Economics Institute of Bard College, 2015. 
PAPADIMITRIOU, D. B.; NIKIFOROS, M.; ZEZZA, G. How Long Before Growth and Employment Are Restored in Greece? Strategic Analysis. Annandale-on-Hudson, NY: Levy Economics Institute of Bard College, 2016.

RITSCHL, A. Does Germany Owe Greece a debt? A historical perspective on the European debt crisis. In:AUSTRIAN NATIONAL BANK (OeNB). Economics Conference 2012: European Monetary Union: lessons from the debt crisis, Vienna, Austria, May 10-11. Vienna: Bank of Austria, 2012a.

RITSCHL, A. Germany, Greece and the Marshall Plan, another riposte. The Economist, July 25, 2012b. Available online at: <http://www.economist.com/blogs/freeexchange/2012/06/ economic-history-2>.

ROCHOLL, J.; STAHMER, A. Where did the Greek bailout money go? ESMT White Paper No. WP-16-02, European School of Management and Technology, Berlin, Germany, 2016.

XAFA, M. Sovereign Debt Crisis Management: Lessons from the 2012 Greek Debt Restructuring. CIGI papers No. 33. Ontario: Centre for International Governance Innovation, 2014.

ZETTELMEYER, J.; TREBESCH, C.; GULATI, M. The Greek debt restructuring: an autopsy. Economic Policy, v.28, n.75, p.513-63, 2013.

\section{About the authors}

Michalis Nikiforos-mnikifor@levy.org

Levy Economics Institute of Bard College. Corresponding author.

Dimitri B.Papadimitriou - dbp@levy.org

Levy Economics Institute of Bard College.

GennaroZezza-zezza@unicas.it

Levy Economics Institute of Bard College.Università degli Studi di Cassino e del Lazio Meridionale, Italy.

\section{About the article}

Submission received on March 16, 2016. Approved for publication on May 11, 2016.

A previous shorter version of this paper appeared as a Levy Economics Institute Policy Note, 2015/2. 